\title{
PHYSICOCHEMICAL AND RHEOLOGICAL CHARACTERIZATION OF AVOCADO OILS
}

\author{
Caracterização físico-química e reológica de óleos de abacate
}

\author{
Tamara de Souza Jorge ${ }^{1}$, Tiago Carregari Polachini ${ }^{1}$, Liara Silva Dias ${ }^{1}$, Neuza Jorge ${ }^{1}$, Javier Telis-Romero ${ }^{2}$
}

\begin{abstract}
Avocado oil is rich in bioactive compounds, which can improve human health by acting as an antioxidant. It may be extracted from different varieties of avocado, such as Margarida and Hass varieties, each of them with particular characteristics. Aiming to evaluate the differences between them, avocado fruits and pulps from these were analyzed according to their physicochemical characteristics. After extracted, the oils had their bioactive characteristics studied and rheological behavior determined through a rotational rheometer. They were then compared to commercial avocado oil. The fruits of Margarida variety had greater size, higher weight $(664.51 \mathrm{~g})$, and higher pulp yield (72.19\%) than Hass variety, which showed higher lipid content (65.29 g/100 g dry basis). The commercial oil showed less primary oxidative degradation, whereas Margarida variety had a lower level of secondary degradation products as well as a higher content of bioactive compounds, such as phytosterols $(999.60 \mathrm{mg} / \mathrm{kg}) \mathrm{and}$ tocopherols $(36.73 \mathrm{mg} / \mathrm{kg})$. The rheological behaviors of both oils were appropriately described through Newton model, with $R^{2}>0.999$ for all temperatures. By an Arrhenius type equation, it was verified that Hass's rheological parameters are more influenced by temperature than Margarida and commercial oil, presenting activation energy of $33.6 \mathrm{~kJ} / \mathrm{mol}$.
\end{abstract}

Index terms: Margarida; Hass; fatty acids; newtonian fluid; Arrhenius.

\section{RESUMO}

O óleo de abacate é rico em compostos bioativos que podem promover melhorias na saúde humana, agindo como um antioxidante. Pode ser extraído de diferentes variedades de frutos de abacate, tais como Margarida e Hass, dando características particulares ao produto. Visando a avaliar as diferenças entre eles, frutas e polpas de abacate dessas variedades foram analisadas de acordo com as suas características físico-químicas. Depois de extraídos, os óleos tiveram suas características bioativas avaliadas e seu comportamento reológico foi determinado por meio de um reômetro rotacional, em comparação com um óleo de abacate comercial. Os frutos da variedade Margarida apresentaram maior tamanho, maior peso $(664,51 \mathrm{~g})$ e rendimento de polpa mais elevado $(72,19 \%)$ do que a variedade Hass, que apresentou maior teor de lipídios (65,29 g/100 g base seca). O óleo comercial evidenciou menor degradação oxidativa primária, ao passo que a variedade Margarida apresentou menor teor de produtos secundários de degradação, bem como maior conteúdo de compostos bioativos, tais como fitosteróis $(999,60 \mathrm{mg} / \mathrm{kg})$ e tocoferóis $(36,73 \mathrm{mg} / \mathrm{kg})$. O comportamento reológico de ambos os óleos foi adequadamente descrito pelo modelo de Newton, com $\mathrm{R}^{2}>0,999$ para todas as temperaturas. Por uma equação tipo Arrhenius, verificou-se que os parâmetros reológicos da variedade Hass são mais influenciados pela temperatura do que Margarida e o óleo comercial, apresentando energia de ativação de 33,6 kJ/mol.

Termos para indexação: Margarida; Hass; ácidos graxos; fluido newtoniano; Arrhenius.

\section{INTRODUCTION}

The avocado (Persea americana Mill) is an original fruit from the American continent, being currently produced in all Brazilian territory. Its cultivation is considered one of the most productive per unit area (Schaffer; Wolstenholme; Whiley, 2013).

Avocado pulp shows outstanding importance due to the $5 \%$ to $30 \%$ oil in its composition, including high contents of saturated fatty acids, such as palmitic $(28 \mathrm{~g} / 100$ $\mathrm{g}$ oil), and monounsaturated fatty acids, mainly oleic acid (30 g/100 g oil) (Soares, Mancini-Filho, Della-Modesta,
1992). These compounds are responsible for providing oxidative stability to the oil. Despite being essential fatty acids, the presence of low contents of polyunsaturated fatty acids, such as linoleic $(5 \mathrm{~g} / 100 \mathrm{~g}$ oil $)$ and $\alpha$-linolenic acid $(1 \mathrm{~g} / 100 \mathrm{~g}$ oil), makes the oil susceptible to oxidative degradation (Villa-Rodríguez et al., 2011). Avocado oil is also a great source of bioactive compounds such as chlorophylls $(655 \mathrm{mg} / \mathrm{kg})$, tocopherols: $\alpha$-tocopherol $(18 \mathrm{mg} / \mathrm{kg})$ and $\gamma$-tocopherol $(90 \mathrm{mg} / \mathrm{kg})$ (RodríguezCarpena; Morcuende; Estévez, 2012), and phytosterols, mainly represented by $\beta$-sitosterol, $251 \mathrm{mg} / \mathrm{kg}$ oil (Berasategi et al., 2012). The presence of tocopherols

\footnotetext{
${ }^{1}$ Universidade Estadual Paulista “Julio de Mesquita Filho"/UNESP - Departamento de Engenharia de Alimentos e Tecnologia - São José do Rio Preto $\mathrm{SP}-$ Brasil

Universidade Estadual Paulista "Julio de Mesquita Filho"/UNESP - Departamento de Engenharia de Alimentos e Tecnologia - São José do Rio Preto - SP — Brasil-javier@ibilce.unesp.br

Received in november 11, 2014 and approved in march 20, 2015
}

Ciênc. Agrotec., Lavras, v. 39, n. 4, p. 390-400, jul./ago., 2015 
provides antioxidant activity to the oil and combats the lipid oxidation (Dias; Menis; Jorge, 2015).

Combining the above cited factors to the great fruit availability along the year, oil extraction can represent an interesting instrument for food industry. It can aggregate value to the fruits and bring profitability to companies (Tango; Carvalho; Soares, 2004). In order to make the avocado oil production feasible on a large scale, the study of its physical properties is necessary to design processing plants.

Rheological properties predict the fluid's resistance and behavior during the flow. Its determination is important in process design, as well as in areas such as cooking and quality control. Since the rheological parameters vary considerably according to the material temperature and composition (Steffe, 1996; Hamm; Hamilton; Calliauw, 2013), their study makes the determination unique for each product.

Several studies have been published, aiming at understanding how the oils composition, particularly the fatty acids, affects their physical parameters (Geller; Goodrum, 2000; Ennouri et al., 2005; Santos; Santos; Souza, 2005). In vegetal oils, the viscosity increases as the fatty acids carbon chain lengthens, and decreases as the unsaturations increase (Kim et al., 2010). Therefore, this rheological parameter is function of the molecules dimensions and orientation (Santos et al., 2004).

Due to the lack of published data regarding the characterization of different avocado oils varieties, this study focused on characterizing bioactively and physicochemically the oils from Hass and Margarida varieties, extracted by centrifugation and compared to a commercial product. Same oils had their rheological behavior determined, with their respective dependence on temperature through an Arrhenius type equation.

\section{MATERIAL AND METHODS}

\section{Fruits}

Two varieties of avocado (Persea americana Mill) were selected. The first one is a variety known as Margarida (Persea americana Mill var. guatemalensis $\mathrm{x}$ Persea americana Mill var. Americana) which was selected due to its availability in the Brazilian market. The other one is Hass (Persea americana Mill var. guatemalensis), and it was chosen due to its high contents of fat. Unripe avocados were picked unit and manually, at a local farm in the city of Rio Paraniba (Minas Gerais State, located at the altitude range from 1100 to $1700 \mathrm{~m}$ ). Fruits were placed in plastic boxes with maximum capacity of $20 \mathrm{~kg}$, brought to the packing house, where fruits with physical damage or deterioration signs were discarded and the good ones stored at room temperature. After reached their maturity stage (Montenegro, 1961), the fruits were taken to the laboratory of oils and fats of the São Paulo State University (São José do Rio Preto, São Paulo, Brazil) and sanitized in order to go through the characterization analyses.

\section{Physical characterization and proximate fruit chemical composition}

Through a random sampling, five units of avocado from each variety were characterized regarding their width and length, and separated in three components: skin, pulp, and pit, and for each of these components the average weight and percentage were determined. The pulp of the varieties Margarida and Hass were characterized regarding the chemical composition, by determining moisture and contents of lipids and ashes, according to AOCS (2009), and of proteins according to AOAC (2005).

\section{Oil extraction}

The oil extraction was conducted in the Empresa de Pesquisa Agropecuária de Minas Gerais - EPAMIG (Maria da Fé, Minas Gerais State, Brazil). During the extraction process, the sanitized fruits had their pulp removed manually and homogenized in a blender. The resulting paste was sifted and kept in a thermal mixer at $40{ }^{\circ} \mathrm{C}$ for 40 minutes. Finally, the paste was placed in a horizontal centrifuge in order to obtain the oil (Oliveira et al., 2010). The extracted oils were filtered, centrifuged, stored in amber glass bottles, and inerted with gaseous nitrogen. Part of the oils was kept in the freezer $\left(-18{ }^{\circ} \mathrm{C}\right)$ until the moment of the analysis. As a comparison, commercial extra virgin cold-pressed avocado oil was used in this study (Grove, New Zealand). For the efficiency calculation, both the obtained paste (before and after the oil extraction), and the oil were weighed.

\section{Physicochemical and bioactive characterization of avocado oils}

The physicochemical characterization analyzes of Margarida, Hass and commercial avocado oils were carried out in accordance with the methodology described by AOCS (2009). Free fatty acids were determined, expressed as oleic acid; peroxide level in milliequivalents of active oxygen per kilogram of oil (meq $/ \mathrm{kg})$; iodine level, which was calculated from the composition in fatty acids and expressed as $\mathrm{g} \mathrm{I}_{2} / 100 \mathrm{~g}$; refractive index at $40{ }^{\circ} \mathrm{C}$; saponification value expressed in $\mathrm{mg} \mathrm{KOH} / \mathrm{g}$; 
unsaponifiable matter expressed as percentage of lipid fraction; chlorophyll expressed in $\mathrm{mg} / \mathrm{kg}$ of oil; conjugated dienes expressed as percentage; $p$-anisidine and oxidative stability in hours. The total polar compounds were measured by using Testo ${ }^{\mathrm{TM}} 270$.

The method described by Bligh and Dyer (1959) was used in the oil extraction destinated to bioactive compounds analyses, to compare the bioactive substances transported by the extraction methods.

The fatty acids profile was obtained by gas chromatography from transesterified samples according to Ce 2-66 (Aocs, 2009). A GC-3900 gas chromatograph (Shimadzu, Kyoto, Japan) equipped with a flameionization detector was used. The fatty acid methyl esters were separated by using a CP-Sil 88 fused-silica capillary column with dimensions of $60 \mathrm{~m}$ width, 0.25 $\mathrm{mm}$ internal diameter, and $0.20 \mu \mathrm{m}$ film thickness. The carrier gas was hydrogen with a flow rate of $30 \mathrm{~mL} / \mathrm{min}$. The fatty acids were identified by comparing the retention times of fatty acids methyl esters pure standards with the samples separate compounds and by co-chromatography. Quantification was obtained by area normalization (\%).

The phytosterols content was evaluated by gas chromatography with the sample prior saponification, according to Duchateau et al. (2002). A GC-FID Plus-2010 gas chromatograph (Shimadzu, Kyoto, Japan) equipped with a flame-ionization detector and RTX 5 capillary column with $30 \mathrm{~m}$ length, $0.25 \mu \mathrm{m}$ film thickness, and $0.25 \mu \mathrm{m}$ internal diameter was used. The carrier gas was hydrogen. Campesterol, stigmasterol, $\beta$-sitosterol, and stigmastanol compounds were identified by comparing the retention times of pure standards and by cochromatography. Quantification was obtained by internal standardization, using $\beta$-cholestanol as internal standard.

Tocopherols were determined by HPLC (High Performance Liquid Chromatograph - Shimadzu, Kyoto, Japan) equipped with fluorescence detector and silica column of $250 \times 4.6 \mathrm{~mm}$, and $5 \mu \mathrm{m}$ pore, according to the Ce 8-89 method, described by AOCS (2009). The mobile phase was made of a mixture of $99.5 \%$ n-hexane and $0.5 \%$ isopropanol, at a flow rate of $1.2 \mathrm{~mL} / \mathrm{min}$. The excitation wavelength was $290 \mathrm{~nm}$, and the emission wavelength was $330 \mathrm{~nm}$. The $\alpha, \beta, \gamma$, and $\delta$-tocopherol compounds were identified by comparing the retention times of pure standards and by co-chromatography. Quantification was obtained by external standardization.

\section{Determining the rheological behavior}

The steady state rheological tests were carried out in a stress-controlled rotational rheometer, model AR-G2
(TA Instruments, New Castle, USA). Its software Rheology Advantage 5.7.1 and the data acquisition system Universal Analysis 20004.7 (both from TA Instruments, New Castle, USA) were used. Concentric cylinder geometry was used, with $5920 \mu \mathrm{m}$ gap and shear rate of 1 to $100 / \mathrm{s}$, in the different temperatures controlled by the equipment itself $\left(20,30,40,50\right.$, and $\left.60^{\circ} \mathrm{C}\right)$.

From the rheograms (shear stress vs shear rate), data were adjusted for each oil at the given temperatures by nonlinear regressions, using the software OriginPro $8.0^{\mathrm{TM}}$ (OriginLab Corporation, Northampton, USA). Regressions were initially adjusted to the Herschel-Bulkley model for non-Newtonian fluids. Equation 1 represents this model, where $\tau$ is the shear stress (Pa), $\dot{\gamma}$ is the shear rate $(1 / \mathrm{s})$, $\tau_{0}$ is the yield stress $(\mathrm{Pa}), k$ is the consistency index $\left(\mathrm{Pa} . \mathrm{s}^{\mathrm{n}}\right)$, and $n$ is the behavior index (dimensionless) (Holdsworth, 1993; Steffe, 1996).

$$
\tau=\tau_{0}+k \dot{\gamma}^{n} \text { for }|\tau|>\tau_{0} \text { for } \dot{\gamma} \neq 0
$$

Three other models can be derived from the Herschel-Bulkley model (Holdsworth, 1993; Steffe, 1996), which are:

Power-law or Ostwald de Waele Model: presents a pseudoplastic behavior $(n<1.0)$ or dilatant behavior $(n>1.0)$ in the absence of yield stress $\left(\tau_{0} \approx 0\right)$, as presented by Equation 2:

$$
\tau=k \dot{\gamma}^{n}
$$

Bingham Model: presents linear dependence between shear rate and shear stress $(n=1.0)$ in the presence of yield stress, as showed by Equation 3, where $\eta_{B}$ (Pa.s) is the plastic viscosity:

$$
\tau=\tau_{0}+\eta_{B} \dot{\gamma} \text { for }|\tau|>\tau_{0} \text { and } \dot{\gamma} \neq 0
$$

Newton Model: purely viscous fluid with $\tau_{0}=0$ and $n=1.0$, as presented by Equation 4, where $\mu(\mathrm{Pa} \mathrm{s})$ is the Newtonian viscosity.

$\tau=\mu \dot{\gamma}$

To what food is concerned, the most important variables which influence the rheological parameters are $\tau_{0}, k, n, \eta_{B}, \mu$, temperature, and composition (Telis-Romero; Telis; Yamashita, 1999; Assis et al., 2006; Tavares et al., 2007). 
In order to quantify the effect of temperature on these parameters, an Arrhenius type equation is generally used (Equation 5), where $A_{0}$ is the pre-exponential factor, $E_{a}(\mathrm{~J} / \mathrm{mol})$ is the activation energy, $R$ is the universal gas constant $(8.314 \mathrm{~J} / \mathrm{K} \mathrm{mol})$, and $T$ is the absolute temperature (K) (Rao; Anantheswaran, 1982):

$$
\tau_{0}, k, n, \eta_{B}, \eta=A_{0} \exp \left(\frac{E_{a}}{R T}\right)
$$

\section{Statistical analysis}

Results obtained were submitted to analysis of variance and to a Tukey test for averages at 95\% of confidence using STATISTICA 7.0 ${ }^{\mathrm{TM}}$ (StatSof Inc., Tulsa, USA).

\section{RESULTS AND DISCUSSION}

\section{Physical characterization and proximate chemical composition of the fruits}

Table 1 presents physical characteristics and proximate composition of the avocados analyzed. Margarida variety fruits were significantly $(p<0.05)$ bigger and presented weight approximately four times higher than the Hass variety. Margarida also presented higher pulp yield of $72.19 \%$ based in the total fruit weight. In a study conducted by Tango, Carvalho and Soares, (2004), the avocado pulp content ranged between 52.9 and $81.3 \%$ of the fruit weight, in the several varieties analyzed.
All the components content differed significantly $(p<0.05)$ between the samples. The lipids were at higher concentration in the Hass variety, $65.29 \mathrm{~g} / 100 \mathrm{~g}$, proving to be a better source of oil. The amount of proteins and ashes were higher in Margarida fruits, with values of 7.17 and $3.94 \mathrm{~g} / 100 \mathrm{~g}$, respectively.

The oil yield from thermal mixer extraction was also analyzed. Margarida pulp showed $7.70 \%$ of oil based on initial paste weight, remaining residual oil (2.25\%) in avocado paste after extraction process. Hass variety fruits obtained higher oil yield, $8.80 \%$, but suffered higher losses during the extraction, since the resulting paste contained $14.28 \%$, a higher content than that extracted by centrifugation.

\section{Physicochemical and bioactive characterization of avocado oils}

Table 2 shows the physicochemical characteristics of the avocado oils. Although the oil from Margarida variety showed the highest acidity level, $3.6 \mathrm{mg} \mathrm{KOH} / \mathrm{g}$, this value is in accordance with international regulations to crude, coldpressed oil, whose threshold is $4 \mathrm{mg} \mathrm{KOH} / \mathrm{g}$ (Codex, 2009).

Peroxides are the main products of primary degradation of autoxidation. Hass oil presented the highest peroxide index, $5.54 \mathrm{meq}_{2} / \mathrm{kg}$, it was also in accordance with the international standard for crude, cold-pressed oils, which is 15.0 meq $\mathrm{O}_{2}$ active/kg oil (Codex, 2009). The oil from the Hass variety studied by Aguiló-Aguayo et al. (2014) presented peroxide value slightly smaller than the one evaluated in this study, 2.27 meq $\mathrm{O}_{2} / \mathrm{kg}$, this diference can be caused by the type of planting, soil fertilization and crop.

Table 1: Physical characteristics and proximate chemical composition of avocados.

\begin{tabular}{lcc}
\hline & & Variety \\
& Margarida & Hass \\
\hline Physical characteristics & & \\
Width $(\mathrm{cm})$ & $10.57 \pm 0.98 \mathrm{a}$ & $6.12 \pm 0.63 \mathrm{~b}$ \\
Length (cm) & $11.83 \pm 1.35 \mathrm{a}$ & $8.85 \pm 0.81 \mathrm{~b}$ \\
Average weight $(\mathrm{g})$ & $664.51 \pm 84.52 \mathrm{a}$ & $169.16 \pm 39.10 \mathrm{~b}$ \\
Pulp (\%) & $72.19 \pm 25.38 \mathrm{a}$ & $64.72 \pm 9.51 \mathrm{~b}$ \\
Pit (\%) & $12.24 \pm 8.83 \mathrm{~b}$ & $14.51 \pm 17.58 \mathrm{a}$ \\
Skin (\%) & $15.57 \pm 61.69 \mathrm{~b}$ & $20.77 \pm 22.03 \mathrm{a}$ \\
Proximate chemical composition (g/100 g dry basis) & \\
Lipids & $49.50 \pm 0.04 \mathrm{~b}$ & $65.29 \pm 0.44 \mathrm{a}$ \\
Protein & $7.17 \pm 0.01 \mathrm{a}$ & $5.66 \pm 0.02 \mathrm{~b}$ \\
Ashes & $3.94 \pm 0.01 \mathrm{a}$ & $3.58 \pm 0.01 \mathrm{~b}$ \\
\hline
\end{tabular}

Means followed by different letters on the same row differ significantly in Tukey's test at $95 \%$ confidence interval. 
Table 2: Physicochemical characteristics of avocado oils.

\begin{tabular}{lcrr}
\hline & \multicolumn{3}{c}{ Variety } \\
& Margarida & \multicolumn{1}{c}{ Hass } & \multicolumn{1}{c}{ Commercial } \\
\hline Acidity $(\mathrm{mg} \mathrm{KOH} / \mathrm{g})$ & $3.64 \pm 0.00 \mathrm{a}$ & $1.58 \pm 0.00 \mathrm{~b}$ & $0.82 \pm 0.00 \mathrm{c}$ \\
Peroxide index $(\mathrm{meq} \mathrm{O} / \mathrm{kg})$ & $4.98 \pm 0.36 \mathrm{ab}$ & $5.54 \pm 0.25 \mathrm{a}$ & $4.80 \pm 0.29 \mathrm{~b}$ \\
Iodine index $(\mathrm{mg} / 100 \mathrm{~g})$ & $80.80 \pm 0.00 \mathrm{c}$ & $82.87 \pm 0.00 \mathrm{~b}$ & $84.70 \pm 0.00 \mathrm{a}$ \\
Refractive index & $1.4615 \pm 0.00 \mathrm{ab}$ & $1.4607 \pm 0.00 \mathrm{a}$ & $1.4632 \pm 0.00 \mathrm{a}$ \\
Saponification value $(\mathrm{mg} \mathrm{KOH} / \mathrm{g})$ & $194.92 \pm 0.02 \mathrm{~b}$ & $195.79 \pm 0.07 \mathrm{a}$ & $193.13 \pm 0.03 \mathrm{c}$ \\
Unsaponifiable matter $(\%)$ & $1.19 \pm 0.09 \mathrm{a}$ & $0.76 \pm 0.03 \mathrm{~b}$ & $1.00 \pm 0.08 \mathrm{a}$ \\
Chlorophyll $(\mathrm{mg} / \mathrm{kg})$ & $3.26 \pm 0.00 \mathrm{c}$ & $10.07 \pm 0.00 \mathrm{~b}$ & $18.96 \pm 0.00 \mathrm{a}$ \\
Total polar compounds $(\%)$ & $7.50 \pm 0.00 \mathrm{~b}$ & $8.83 \pm 0.29 \mathrm{a}$ & $5.67 \pm 0.29 \mathrm{c}$ \\
Conjugated dienes $(\%)$ & $0.15 \pm 0.00 \mathrm{~b}$ & $0.20 \pm 0.01 \mathrm{a}$ & $0.19 \pm 0.01 \mathrm{a}$ \\
$\rho$-anisidine & $0.04 \pm 0.00 \mathrm{c}$ & $0.95 \pm 0.00 \mathrm{a}$ & $0.82 \pm 0.00 \mathrm{~b}$ \\
Oxidative stability index $(\mathrm{h})$ & $3.87 \pm 0.08 \mathrm{c}$ & $5.57 \pm 0.07 \mathrm{~b}$ & $6.31 \pm 0.18 \mathrm{a}$ \\
\hline
\end{tabular}

Means followed by different letters on the same row differ significantly in Tukey's test at $95 \%$ confidence interval; nd (not detected).

The iodine index was lower in Margarida's oil, indicating a higher presence of saturated fatty acids in relation to the unsaturated ones, due to a lower incorporation of iodine atoms in the fatty acid molecule. The commercial oil showed higher iodine level, indicating higher unsaturation degree, which can be correlated with the refractive index, which was also higher than the other oils.

The saponification number allows us to obtain an estimate of the average length of the fatty acids chain (Nielsen, 2010). The result for the saponification number was higher in Hass variety (195.79 mg KOH/g). Margarida and the commercial oils did not differ significantly $(p>$ 0.05 ) to what unsaponifiable matter was concerned; in this fraction there are bioactive compounds, which are responsible for the antioxidant activity of food, and for fighting cell aging; among them, there are phytosterols, tocopherols, and carotenoids (Fontanel, 2013). The commercial avocado oil showed the highest chlorophyll content compared to the other oils analyzed, $18.96 \mathrm{mg} / \mathrm{kg}$, which grants a darker green color to it.

According to Lumley (1988) the percentage of polar compounds in new oils, which have not yet been used, must be between 0.4 and $6.4 \%$. Thus, the avocado oils used in this study can be considered altered, because they showed a level of $7.50 \%$ for Margarida and $8.83 \%$ for Hass. The commercial avocado oil presented the lowest content of total polar compounds, $5.67 \%$, and was the only sample in accordance with the limits recommended by literature.

The conjugated dienes content indicates the formation of primary degradation compounds, whereas the $p$-anisidine content indicates the secondary degradation products in oil. We can infer, therefore, that Margarida oil was in a better conservation state than Hass oil, due to its lower conjugated dienes content, $0.15 \%$, and $p$-anisidine, 0.04 , which indicate good conservation state. However, its oxidative stability index was the lowest, 3.87 hours, due to a higher acidity level in that oil. Salgado et al. (2008) studied Margarida oil and found: $0.91 \%$ of free fatty acids; peroxide value of $20.58 \mathrm{meq} \mathrm{O}_{2} / \mathrm{kg}$; iodine value of 96.31 $\mathrm{mg} \mathrm{I} / 100 \mathrm{~g}$; saponification number of $184.10 \mathrm{mg} \mathrm{KOH} / \mathrm{g}$; and $1.72 \%$ of unsaponifiable matter. Among the studied oils, it was observed that the commercial oil presented lower values for free fatty acids, peroxides, and total polar compounds; it was also noticed that it contained significant amounts of unsaponifiable matter, and, consequently, a higher oxidative stability index.

Table 3 presents the bioactive compounds present in the analysed avocado oils. It was noted a substantial difference between the fatty acids concentration in the studied oils.

The oils contained, as their main components, palmitic, oleic, and linoleic acids; however, the proportion among these components varied.

The commercial avocado oil presented the highest concentration of oleic acid, $73.88 \mathrm{~g} / 100 \mathrm{~g}$, n-9 monounsaturated fatty acid which helps decreasing plasma LDLc, without decreasing HDLc, therefore reducing the risk of cardiovascular diseases. Hass variety showed a higher amount of palmitoleic acid, $11.35 \mathrm{~g} / 100 \mathrm{~g}$, another important n-9 fatty acid, which can be found in higher concentrations in oils from ocean animals. 
Table 3: Bioactive compounds present in avocado oils.

\begin{tabular}{lrrr}
\hline & Margarida & Hass & Commercial \\
\hline Fatty acids (g/100 g oil) & & & \\
Palmitic $(16: 0)$ & $23.28 \pm 0.05 \mathrm{a}$ & $19.43 \pm 0.00 \mathrm{~b}$ & $11.74 \pm 0.00 \mathrm{c}$ \\
Palmitoleic (16:1) & $2.65 \pm 0.02 \mathrm{c}$ & $11.35 \pm 0.01 \mathrm{a}$ & $4.08 \pm 0.02 \mathrm{~b}$ \\
Oleic $(18: 1)$ & $57.33 \pm 0.04 \mathrm{~b}$ & $54.72 \pm 0.02 \mathrm{c}$ & $73.88 \pm 0.02 \mathrm{a}$ \\
Linoleic $(18: 2)$ & $14.84 \pm 0.04 \mathrm{a}$ & $13.22 \pm 0.01 \mathrm{~b}$ & $9.51 \pm 0.03 \mathrm{c}$ \\
Linolenic (18:3) & $1.25 \pm 0.02 \mathrm{a}$ & $0.83 \pm 0.00 \mathrm{~b}$ & $0.32 \pm 0.01 \mathrm{c}$ \\
Others & $0.66 \pm 0.01 \mathrm{a}$ & $0.45 \pm 0.01 \mathrm{~b}$ & $0.43 \pm 0.01 \mathrm{~b}$ \\
Phytosterols (mg/kg oil) & & & \\
Campesterol & $18.50 \pm 0.01 \mathrm{a}$ & $14.10 \pm 0.06 \mathrm{~b}$ & $7.80 \pm 0.01 \mathrm{c}$ \\
$\beta$-sitosterol & $822.90 \pm 0.02 \mathrm{a}$ & $769.50 \pm 0.02 \mathrm{~b}$ & $624.30 \pm 0.11 \mathrm{c}$ \\
Stigmastanol & $11.20 \pm 0.01 \mathrm{a}$ & $8.30 \pm 0.03 \mathrm{~b}$ & $11.40 \pm 0.06 \mathrm{a}$ \\
$\Delta^{5}$-avenasterol & $11.20 \pm 0.01 \mathrm{a}$ & $13.70 \pm 0.21 \mathrm{a}$ & $10.90 \pm 0.06 \mathrm{a}$ \\
$\Delta^{7}$-avenasterol & $135.80 \pm 0.18 \mathrm{a}$ & $137.50 \pm 0.14 \mathrm{a}$ & $101.20 \pm 0.01 \mathrm{~b}$ \\
Total & $999.60 \pm 0.16 \mathrm{a}$ & $943.10 \pm 0.35 \mathrm{~b}$ & $755.60 \pm 0.12 \mathrm{c}$ \\
Tocopherols (mg/kg oil) & & & \\
$\alpha$-tocopherol & $36.73 \pm 0.25 \mathrm{a}$ & $30.47 \pm 0.46 \mathrm{~b}$ & $28.83 \pm 0.06 \mathrm{c}$ \\
$\gamma$-tocopherol & nd & nd & $2.03 \pm 0.06$ \\
Total & $36.73 \pm 0.25 \mathrm{a}$ & $30.47 \pm 0.46 \mathrm{~b}$ & $30.87 \pm 0.06 \mathrm{~b}$ \\
Vitamin E (UI/kg) & $40.41 \pm 0.05 \mathrm{a}$ & $33.52 \pm 0.02 \mathrm{~b}$ & $32.02 \pm 0.04 \mathrm{c}$ \\
\hline
\end{tabular}

Means followed by different letters on the same row differ significantly in Tukey's test at 95\% confidence interval; nd (not detected).

Margarida variety showed higher amounts of polyunsaturated n- 6 and n-3 fatty acids, linoleic (14.84 $\mathrm{g} / 100 \mathrm{~g})$ and $\alpha$-linolenic $(1.25 \mathrm{~g} / 100 \mathrm{~g})$, respectively. These are essential fatty acids, extremely important to humans. This variety also showed a higher content of palmitic acid, a saturated fatty acid, which is responsible for stability during the thermal processing treatment and resistance to oxidative reactions.

In the study of avocado oil from Hass variety originary from Chile, Peru and Spain conducted by Donetti and Terry (2014), oleic acid was the main fatty acid in all analyzed samples, with the average content of $53 \%$, followed by palmitic $(20 \%)$, linoleic $(14 \%)$, palmitoleic (7\%), and $\alpha$-linolenic acid (4\%).

\section{Rheological behavior}

The Herschel-Bulkley model was adjusted to the shear stress and shear rate data for each oil at a specific temperature. The adjustment parameters are in Table 4, where $R^{2}>0.9999$ was obtained in all regressions.
Through the adjustment parameters, it could be observed that all oil varieties showed yield stress values $\tau_{0} \approx 0$ and the flow behavior index was very close to 1 . These facts lead to conclude that all the studied oils presented a Newtonian behavior, where shear stress is a linear function of the shear rate without linear coefficient. In this function, the angular coefficient, before represented by $k$ in the Herschel-Bulkley equation, can be approximated to Newtonian viscosity, expressed by $\mu$.

In order to better evaluate the values, linear regressions were carried out to obtain the exact values to the Newtonian viscosity contained in Table 5 .

Although short studies about the rheology of avocado oil such as Logaraj et al. (2008) have come to a conclusion of a non-Newtonian behavior, no yield stress was identified and its pseudoplasticity is moderate, with a flow behavior index of 0.88 .

By evaluating higher shear rate values, data shows a linear trend for the same temperature both in Logaraj 
et al. (2008), and this study (Figure 1). According to Steffe (1996) and Timms (1985), vegetal oils are typical examples of Newtonian fluids, with viscosity independent from shear rate. Moreover, oils usually present a Newtonian behavior due to the presence of long-chain fatty acids in their composition (Maskan, 2003; Santos et al., 2004). This affirmation can be confirmed by the study of Antunes, Lanza and Hense (2013) about rice bran oil. The crude and degummed oils presented Newtonian behavior in the temperature interval of 30 to $90{ }^{\circ} \mathrm{C}$, with $R^{2}$ values varying between 0.97 and 1.00 .

Due to each $\pi$ bond contained in a cis configuration fatty acid, a fold may occur in a straight chain, avoiding the chains to be close to each other (Abramovic; Klofutar, 1998), i. e. fatty acids with more double bonds do not present a rigid, fixed structure, thus becoming less tightly packed and less viscous (Kim et al., 2010). Since the commercial oil showed a higher percentage of unsaturated fatty acids, it was expected to have less viscosity when compared to other oils. According to the same logic, Margarida oil should present more viscosity because it contains less unsaturation. However, its composition showed a higher number of polyunsaturated fatty acids, when compared to Hass, constituting an even less tightly packed and viscous structure.

Table 4: Rheograms adjustment parameters of each oil to Herschel-Bulkley equation at the different temperatures.

\begin{tabular}{ccccc}
\hline Rheological parameters & Temperature $\left({ }^{\circ} \mathrm{C}\right)$ & Margarida & Hass & Commercial \\
\hline & 20 & 0.0003 & 0.0490 & 0.0056 \\
$\tau_{0}(\mathrm{~Pa})$ & 30 & 0.0398 & 0.0684 & 0.0367 \\
& 40 & 0.0446 & 0.0437 & 0.0438 \\
& 50 & 0.0407 & 0.0365 & 0.0398 \\
& 60 & 0.0316 & 0.0326 & 0.0343 \\
\hline \multirow{2}{*}{$\left(\mathrm{Pa} . \mathrm{s}^{\mathrm{n}}\right)$} & 20 & 0.0807 & 0.0999 & 0.0808 \\
& 30 & 0.0472 & 0.0543 & 0.0484 \\
& 40 & 0.0298 & 0.0295 & 0.0304 \\
& 50 & 0.0201 & 0.0200 & 0.0204 \\
& 60 & 0.0142 & 0.0139 & 0.0141 \\
\hline & 20 & 1.0087 & 0.9856 & 1.0093 \\
& 30 & 1.0218 & 1.0039 & 1.0196 \\
& 40 & 1.0319 & 1.0319 & 1.0303 \\
& 50 & 1.0392 & 1.0382 & 1.0388 \\
& 60 & 1.0466 & 1.0478 & 1.0472 \\
\hline
\end{tabular}

Table 5: Newtonian viscosity values (Pa.s) for the avocado oils.

\begin{tabular}{cccc}
\hline Temperature $\left({ }^{\circ} \mathrm{C}\right)$ & & Viscosity (Pa.s) & Commercial \\
\hline 20 & Margarida & Hass & 0.08589 \\
30 & 0.0854 & 0.09116 & 0.05503 \\
40 & 0.05446 & 0.05587 & 0.03719 \\
50 & 0.03675 & 0.03634 & 0.02631 \\
60 & 0.02599 & 0.02578 & 0.01929 \\
\hline
\end{tabular}


a)

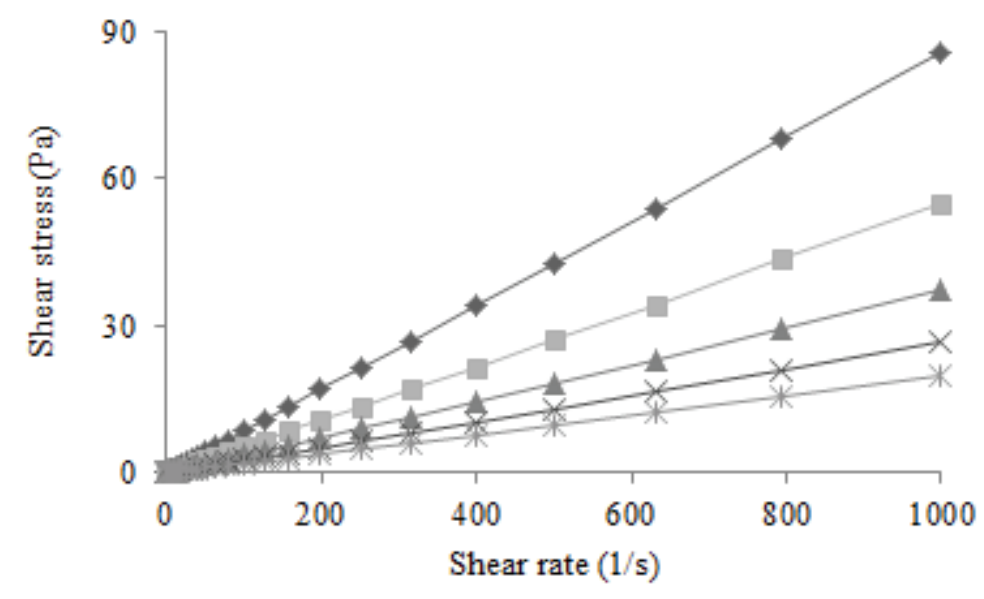

b)

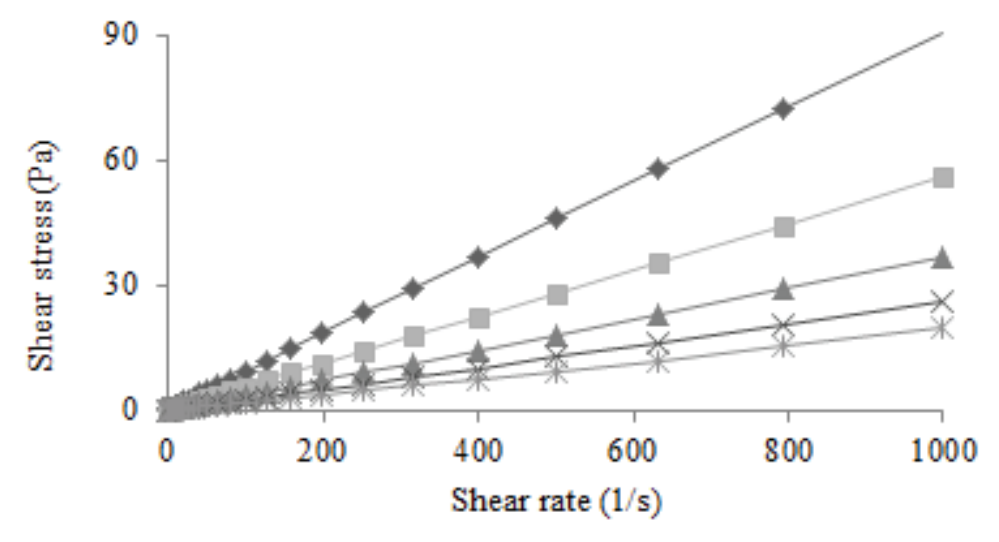

c)

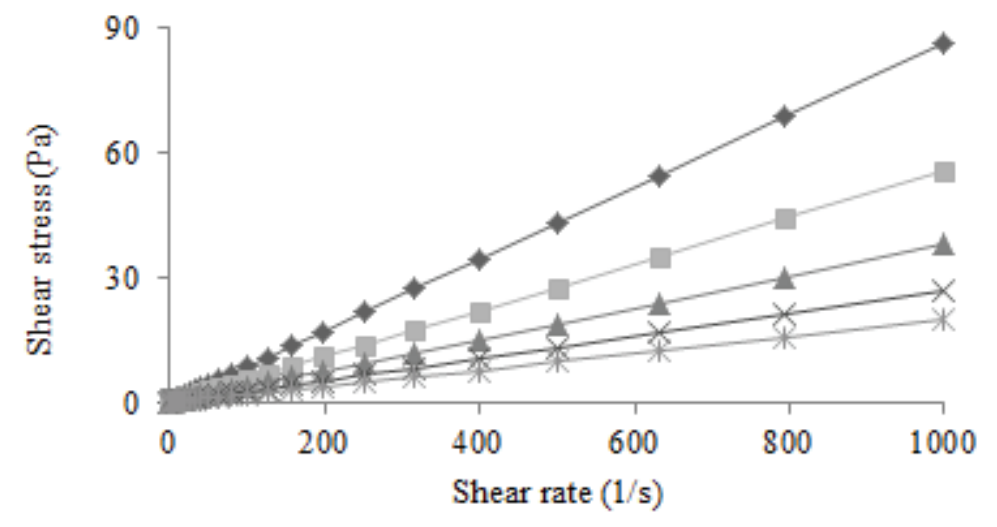

$\rightarrow-20^{\circ} \mathrm{C}-30^{\circ} \mathrm{C} \rightarrow 40{ }^{\circ} \mathrm{C} \nsucc 50^{\circ} \mathrm{C} \rightarrow 60^{\circ} \mathrm{C}$

Figure 1: Rheograms obtained for oils from Margarida (a), Hass (b), and commercial (c) varieties. 
Noting the obtained viscosity values, a decrease was verified as temperature increases in a non linear way. This phenomenon happens because intermolecular forces are weakened as their agitation increases, making their movements and flow easier (Kahn et al., 1990). In order to verify the influence of temperature on the rheological parameters, particularly on viscosity, an Arrhenius equation was adjusted with fitting parameters shown on Table 6.

Table 6: Arrhenius equation adjustment parameters.

\begin{tabular}{lccc}
\hline Parameters & Margarida & Hass & Commercial \\
\hline$A_{0}(\mathrm{~Pa} . \mathrm{s})$ & $2.1958 \times 10^{-7}$ & $9.2934 \times 10^{-8}$ & $2.3345 \times 10^{-7}$ \\
$E_{a}(\mathrm{~J} / \mathrm{mol})$ & 31351.48 & 33600.10 & 31218.07 \\
$R^{2}$ & 0.9985 & 0.9969 & 0.9989 \\
\hline
\end{tabular}

By and large, the higher the activation energy value is, the higher the viscosity variation with a change in temperature is. Hass oil was more temperature-dependent, followed by Margarida, and the commercial oil, with activation energy ranging between 43.74 and $36.53 \mathrm{~kJ} /$ mol. Values close to $30 \mathrm{~kJ} / \mathrm{mol}$ have been found in refined commercial oils from different sources (Blayo; Gandini; Le Nest, 2001; Kim et al., 2010). Kim et al. (2010) also suggests that oils with more double bonds have lower activation energies, resulting in the obtained data by this present study.

\section{CONCLUSIONS}

The extraction process by centrifugation obtained high yield in oil, which attests that it is a viable process, applicable in food industries. However, due to its high acidity and peroxide levels, an improvement is necessary, in order to avoid its oxidative degradation. Among the studied varieties, Hass showed higher lipid contents in the pulp, possibly the best option for oil extraction. On the other hand, Margarida oil presented a higher content of polyunsaturated fatty acids and bioactive compounds. Both varieties constituted sources of oleic and linoleic fatty acids, besides vitamin E, and $\beta$-sitosterol. Newton's Model described the Newtonian behavior of the studied avocado oils appropriately across temperatures of $20-60{ }^{\circ} \mathrm{C}$. The temperature variation has a higher effect on Hass variety's viscosity, which also presented higher activation energy $(33.6 \mathrm{~kJ} / \mathrm{mol})$.

\section{ACKNOWLEDGMENT}

The authors acknowledge financial support from CAPES (Coordenação de Aperfeiçoamento de Pessoal de Nível Superior).

\section{REFERENCES}

ABRAMOVIC, H.; KLOFUTAR, C. The temperature dependence of dynamic viscosity for some vegetable oils. Acta Chimica Slovenica. 45(1):69-77, 1998.

AGUILÓ-AGUAYO, I. et al. Impact of pulsed light treatments on quality characteristics and oxidative stability of fresh-cut avocado. LWT - Food Science and Technology. 59(1):320-326, 2014.

ANTUNES, S. A.; LANZA, M.; HENSE, H. Rheological properties of rice bran (Oryza sativa L.) oils processing and soapstock distillation residue. Industrial Crops and Products. 46(0):111-116, 2013.

AOAC. Official Methods of Analysis. Washington, D. C.: Association of Official Analytical Chemists. 2005.

AOCS. Official and tentative methods of the American Oil Chemists' Society: including additions and revisions. Champaign: AOCS Press. 2009.

ASSIS, M. et al. Influence of temperature and concentration on thermophysical properties of yellow mombin (Spondias mombin, L.). European Food Research and Technology. 223(5):585-593, 2006.

BERASATEGI, I. et al. Stability of avocado oil during heating: Comparative study to olive oil. Food Chemistry. 132(1):439-446, 2012.

BLAYO, A.; GANDINI, A.; LE NEST, J.-F. Chemical and rheological characterizations of some vegetable oils derivatives commonly used in printing inks. Industrial Crops and Products. 14(2):155-167, 2001.

BLIGH, E. G.; DYER, W. J. A Rapid method of total lipid extraction and purification. Canadian Journal of Biochemistry and Physiology. 37(8):911-917, 1959.

\section{CODEX. Current official Standards - CODEX STAN (210). Standard for Named Vegetable Oils. 2009.}

DIAS, L. S.; MENIS, M. E. C.; JORGE, N. Effect of rosemary (Rosmarinus officinalis) extracts on the oxidative stability and sensory acceptability of soybean oil. Journal of the Science of Food and Agriculture. 95(10):2021-2027, 2015. 
DONETTI, M.; TERRY, L. A. Biochemical markers defining growing area and ripening stage of imported avocado fruit cv. Hass. Journal of Food Composition and Analysis. 34(1):90-98, 2014.

DUCHATEAU, G. S. M. J. E. et al. Fast and accurate method for total 4-desmethyl sterol(s) content in spreads, fat-blends, and raw materials. Journal of the American Oil Chemists' Society. 79(3):273-278, 2002.

ENNOURI, M. et al. Fatty acid composition and rheological behaviour of prickly pear seed oils. Food Chemistry. 93(3):431-437, 2005.

FONTANEL, D. Unsaponifiable Matter in Plant Seed Oils. Springer, 2013.

GELLER, D. P.; GOODRUM, J. W. Rheology of vegetable oil analogs and triglycerides. Journal of the American Oil Chemists' Society. 77(2):111-114, 2000 .

HAMM, W.; HAMILTON, R. J.; CALLIAUW, G. Edible Oil Processing. Wiley, 2013.

HOLDSWORTH, S. D. Rheological models used for the prediction of the flow properties of food products: a literature review. Food and Bioproducts Processing: Transactions of the Institution of of Chemical Engineers, Part C. 71(3):139-179, 1993.

KAHN, R. et al. Activity and mobility of water in sweetened concentrated desludged soy beverages and their rheological properties. Journal of Food Science. 55(2):537-542, 1990.

KIM, J. et al. Correlation of fatty acid composition of vegetable oils with rheological behaviour and oil uptake. Food Chemistry. 118(2):398-402, 2010.

LOGARAJ, T. V. et al. Rheological behaviour of emulsions of avocado and watermelon oils during storage. Food Chemistry. 106(3):937-943, 2008.

LUMLEY, I. D. Polar compounds in heated oils. In: VARELA, G. et al. (Ed.). Frying of food, principles, changes, new approaches. London: $\mathrm{VCH}, 1988$. p.166.
MASKAN, M. Change in colour and rheological behaviour of sunflower seed oil during frying and after adsorbent treatment of used oil. European Food Research and Technology. 218(1):20-25, 2003.

MONTENEGRO, H. W. S. A cultura do abacateiro. São Paulo: Editora Melhoramentos, 1961.

NIELSEN, S. S. Food Analysis. Springer, 2010.

OLIVEIRA, A. F. et al. Óleo de abacate, uma alternativa para o azeite de oliva. Belo Horizonte: Empresa de Pesquisa Agropecuária de Minas Gerais. 114: 2010, p.1-5, 2010.

RAO, M. A.; ANANTHESWARAN, R. C. Rheology of fluids in food-processing. Food Technology. 36(2):116-126, 1982.

RODRÍGUEZ-CARPENA, J. G.; MORCUENDE, D.; ESTÉVEZ, M. Avocado, sunflower and olive oils as replacers of pork back-fat in burger patties: Effect on lipid composition, oxidative stability and quality traits Meat Science. 90(1):106-115, 2012.

SALGADO, J. M. et al. O óleo de abacate (Persea americana Mill) como matéria-prima para a indústria alimentícia. Food Science and Technology. 28:20-26, 2008.

SANTOS, J. et al. Thermoanalytical, kinetic and rheological parameters of commercial edible vegetable oils. Journal of Thermal Analysis and Calorimetry. 75(2):419-428, 2004.

SANTOS, J. C. O.; SANTOS, I. M. G.; SOUZA, A. G. Effect of heating and cooling on rheological parameters of edible vegetable oils. Journal of Food Engineering. 67(4):401-405, 2005.

SCHAFFER, B. A.; WOLSTENHOLME, B. N.; WHILEY, A. W. The Avocado: Botany, Production and Uses. CABI, 2013. 540p.

SOARES, S. E.; MANCINI-FILHO, J.; DELLAMODESTA, R. C. Sensory detection limits of avocado oil in mixtures with olive oil. Revista Española de Ciencia y Tecnologia de Alimentos. 32(5):509-516, 1992. 
STEFFE, J. F. Rheological Methods in Food Process

Engineering. 2. East Lansing: Freeman Press, 1996. 418 p.

TANGO, J. S.; CARVALHO, C. R. L.; SOARES, N. B. Physical and chemical characterization of avocado fruits aiming its potencial for oil extraction. Revista Brasileira de Fruticultura. 26:17-23, 2004.

TAVARES, D. T. et al. Rheological properties of frozen concentrated orange juice (FCOJ) as a function of concentration and subzero temperatures. International Journal of Food Properties. 10(4):829-839, 2007.
TELIS-ROMERO, J.; TELIS, V. R. N.; YAMASHITA, F. Friction factors and rheological properties of orange juice. Journal of Food Engineering. 40(1):101-106, 1999.

TIMMS, R. E. Physical properties of oils and mixtures of oils. Journal of the American Oil Chemists' Society. 62(2):241-249, 1985.

VILLA-RODRÍGUEZ, J. A. et al. Effect of maturity stage on the content of fatty acids and antioxidant activity of 'Hass' avocado. Food Research International. 44(5):1231-1237, 2011. 